\title{
著明な骨新生を伴った上顎悪性エナメル上皮腫の病理組織学的検討
}

\author{
有家巧・森田章介・中嶋正博 \\ 堀井活子・岡野博 郎
}

\section{Histo-pathological study of a malignant ameloblastoma associated with prominent new bone formation of the maxilla}

\author{
Takumi Arika - Shosuke Morita • Masahiro Nakajima \\ Katsuko HoriI • Hakuro OKano
}

\begin{abstract}
The classification for odontogenic tumors of the World Health Organization was revised 21 years after first being issued. The term "malignant ameloblastoma" has been especially controversial because there was special emphasis on metastasis without a statement on histology in the former WHO classification. According to the revised WHO classification, malignant ameloblastoma is a neoplasm in which the pattern of an ameloblastoma and cytological features of malignancy are shown by the primary growth in the jaws and/or by any metastatic growth.

This paper presents an extremely rare malignant ameloblastoma of the maxilla which histologically showed malignant features together with prominent new bone formation. The patient was a 46-year-old Japanese female who visited our hospital complaining of pain in the right upper premolar region. An incision had been made in the second premolar region and the second premolar had been extracted 2 months before her initial visit. At physical examination, diffuse swelling was observed in the right cheek and maxilla alveolus; the overlying mucosa of the alveolar process and palate displayed redness. Orthopantomogram revealed a ground-glass appearance extending from the canine to the second molar, and the right antrum was pushed upward. CT X-ray revealed new bone formation in the right maxilla and just outside of the anterior wall of the maxilla. The tentative diagnosis was sclerosing osteomyelitis or fibro-osseous lesion. However, biopsy specimen examination revealed an ameloblastoma with cytological malignancy. We performed right hemimaxillectomy under general anesthesia. Histologically, most of the tumor showed the pattern of a follicular ameloblastoma which consisted of basaloid cells. Atypical cells including hyperchromatism, increased N/C ratio and mitosis were also observed. Vigorous bone formation was seen throughout tumor, but bone destruction by the tumor was also observed in some parts. New bony trabeculae were surrounded by many active osteoblasts. The nests or sheets of the tumor were observed among new bone. Partial resection of the left maxilla was performed because recurrence of the tumor was detected in the resected margin of the palate about 2 years after the first operation. The postoperative course has been uneventful after the second operation, and no recurrence or metastases have been observed for 7 years.
\end{abstract}

大阪歯科大学口腔外科学第 2 講座

(主任：岡野博郎教授)

Second Department of Oral and Maxillofacial Sur- gery, Osaka Dental University (Chief: Prof. Hakuro Okano)

受付日：平成 4 年 12 月 20 日 
Key words: malignant ameloblastoma (悪性エナィル上皮腫), maxilla (上顎), bone formation (骨形成)

緒

言

悪性エナメル上皮腫はまれな腫瘍であるが，その定義 については議論があった。1992年に WHO の歯原性腫 瘍の分類が 21 年ぶりに改訂され, 悪性エナメル上皮腫に 関しても, 従来の転移を有するエナィル上皮腫から転移 の有無にかかわらず, 細胞学的に悪性像が認められるも のと変更された ${ }^{1)}$. 今回われわれは著明な骨新生を伴っ た, きわめてまれな上䫟の悪性エナメル上皮腫を経験し 組織学的検討を行ったので報告する。

\section{症}

例

患 者: 46歳 女性.

初 診：昭和58年 4 月曰日.

主 訴：右側上顎小臼歯部の疼痛.

既往歴：特記事項なし。

現病歴：昭和 57 年 11 月頃より $\underline{5}$ | 部の腫脹沶よび疼痛 があり，昭和58年 2 月某歯科を受診した。歯性感染症の 診断で切開を受けたか゚症状が軽減せず， 5 |を抜歯され た。しかしな和症状に変化がないため紹介され来院し た。

現 症 : 口腔外所見としては, 右側煩部から同側の鼻 翼外側部にびまん性の骨様硬の腫脹を認めた（写真 1 ). 領域リンパ節の腫脹は認められなかった。腔内所見と しては, $7-3 \mid$ 部頓側歯肉特よび口蓋粘膜は軽度発赤し, びまん性の腫脹を認めたが 圧痛はなかった。 $\underline{5}$ 拔歯窩 壁には肉芽組織が認められたが，探針を挿入すると易出 血性で粗造な骨面を触知した。

$\mathbf{X}$ 線所見：右側上䋶洞は上方へ圧排され， $\underline{7-3} \mid$ 飞相 当する骨体部はスリガラス様を呈していた（写真 2 ）.

骨や歯根の吸收像は認められなかった。 X線 CT 写真 では右側上顎洞部には腫瘍性陰影が認められ, 同部拉よ び上顎骨前壁に雲状の骨形成像が観察された（写真 3 ).

臨床検査所見：特記事項なし。

臨床診断：右側上顎骨の硬化性骨䯣炎あるいは線維・ 骨性病変.

生 検：同年 4 月回日に $\underline{5}$ 部より生検を行った。線 維性結合組織中に立方形初よび紡錘形細胞が島状あるい は索状に增殖し, 一部の細胞に大小不同, N/C 比の増 大, 過クロマチン症などの異型性が認められた（写真 4)、な㟫管状構造はみられず, PAS 染色陰性であっ た。 以上の所見から悪性エナメル上皮腫 (ameloblastic carcinoma）が強く疑われた。

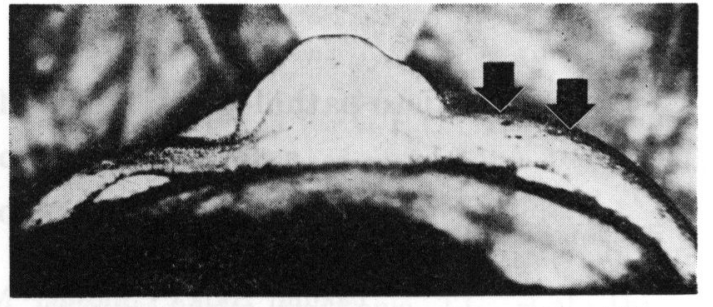

写真 1 初訩時, 頭頂よりみた頓部の腫脹（〕）

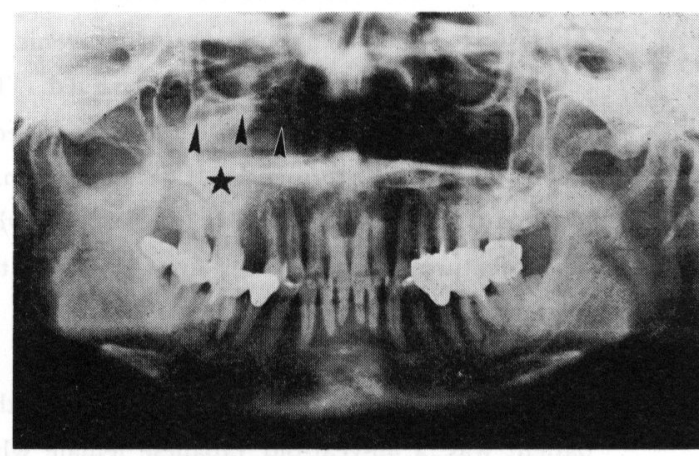

写真 2 初診時のオルソパソトモグラム

7〜3| 部では根尖から上顎洞底（）はでスリガラス 様陰影を認める $(\star)$.

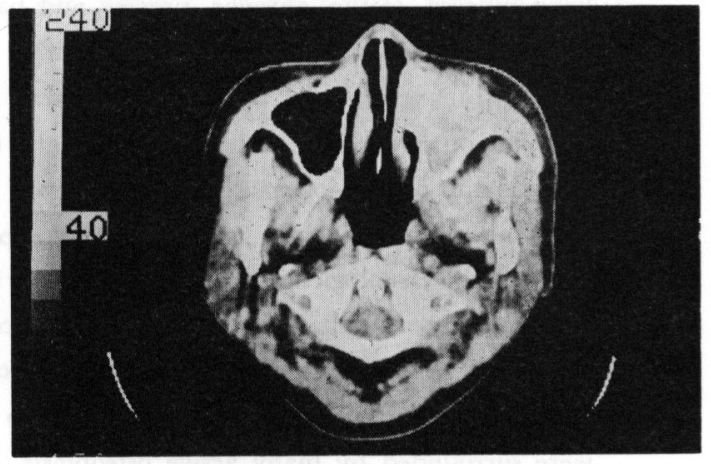

写真 3 初診時の X線 CT 写真

右側上䫇洞部には腄瘍性陰影がみられ，同部から上 頸骨前壁に骨形成像が認められる。

処置および経過 : 昭和 58 年 5 月⿴日全身麻酔下で, Weber 切開を用い右側上顎骨全摘出術を施行した。術後 経過は良好であったが昭和 60 年 10 月中旬, 口蓋前方部の 切除断端粘膜に発赤を伴 5 腫脹を認めた (写真 5 ). $\mathrm{X}$ 線写真では特異な所見はみられなかったが, 生検を行っ 


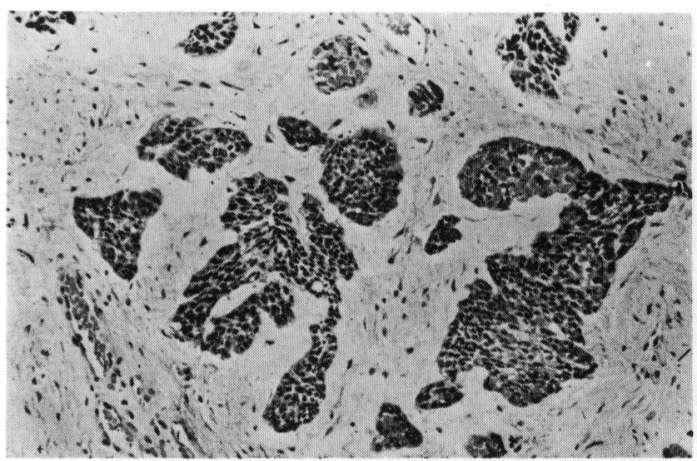

写真 4 生検標本の組織写真

島状や索状の胞栄がみられ, 一部の細胞に異型性を 認める(H-E 染色, 強拡大).

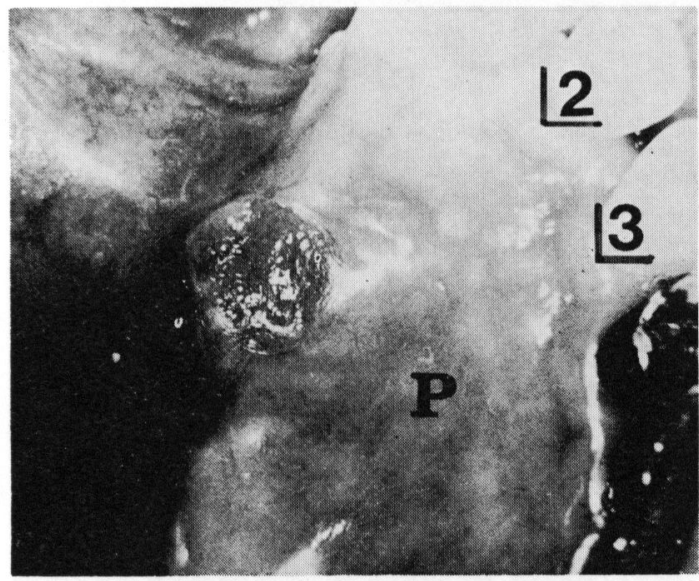

写真 5 再発時の口内写真

切除断端に腫瘍の再発がみられる。 P : 左側口蓋.

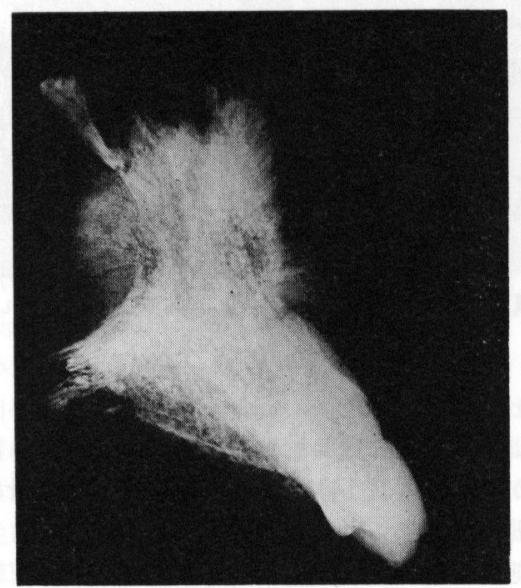

写真 6 初回切除標本の軟X線写真 旭日像が認められる。

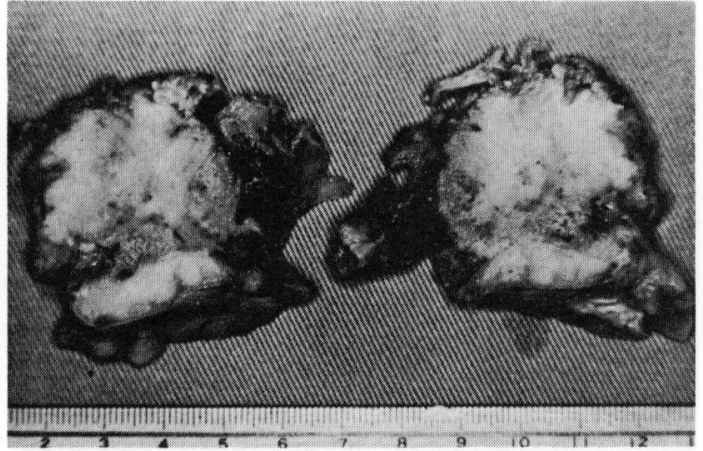

写真 7 割面写真

灰白色，充実性である。

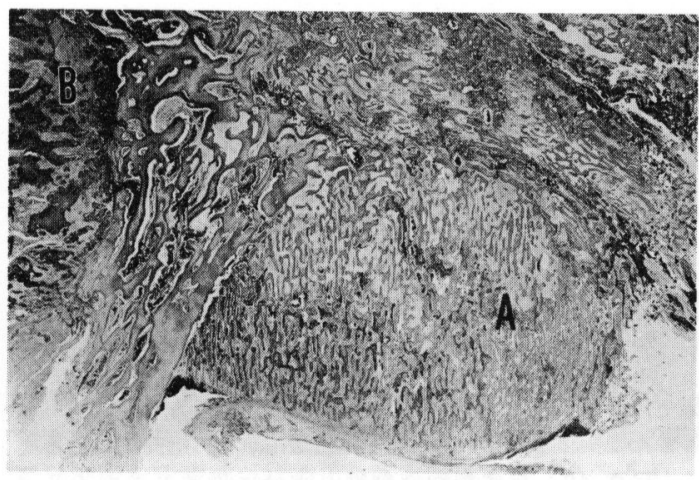

写真 8 初回切除標本の弱拡大組織写真
$\mathrm{A}$ ：新生骨の形成が著明な部.
B：胞巣が密に增殖している部。

(H-E 染色, 弱拡大)

たところ, 初回摘出標本と同様な所見であり, 腫瘍の再 発と診断した。同年12月日日に腫瘍部の辺縁から約 1.5 $\mathrm{cm}$ 離れた健康組織を含め左側上顎骨部分切除術を施行 した. 現在, 再手術後 7 年を経過しているが, 再発およ び肺などへの転移は認められない。

初回手術時の切除標本の所見 :

1 ) 軟X線写真所見; 上顮骨の前壁および上頭洞側に 旭日像が認められた（写真 6 ).

2 ) 割面所見; 灰白色, 充実性で硬さは弾性硬, 粗造 であった（写真 7).

3 ）病理組織所見; 腫瘍は主に胞巣が比較的密に増殖 している部と, 新生骨の形成が顕著でそれらの間に胞巣 が認められる部からなっていた（写真 8 ). 典型的なエ ナメル上皮腫の像を示す部（写真9）は少なく, 胞巣は 基底細胞様細胞の増殖からなるものが多く, それらの内 部には角化巣が点在していた（写真 10). 全体的な細胞 の異型性は軽度であったが, クロマチンに富み, 細胞や 核の大小不同, 分裂像なと゚が顕著な部が散在性に認めら 


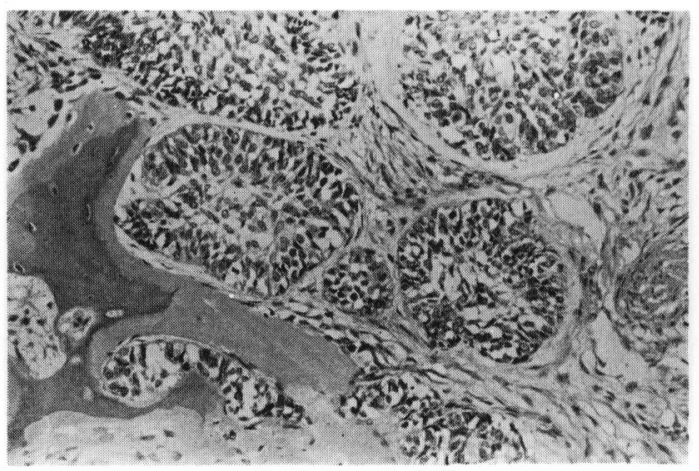

写真 9 胞巣は滤胞状を示している(H-E 染色, 強桩大).

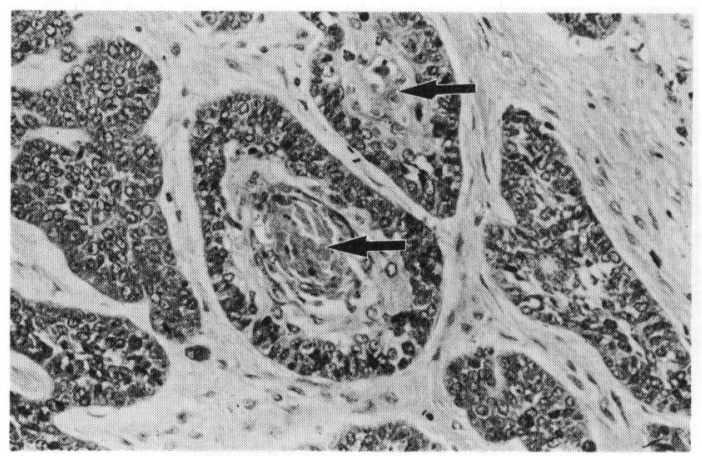

写真 10 基底細胞様細胞が高状に増殖している。 （ ）: 角化巣 (H-E 染色, 強拡大).

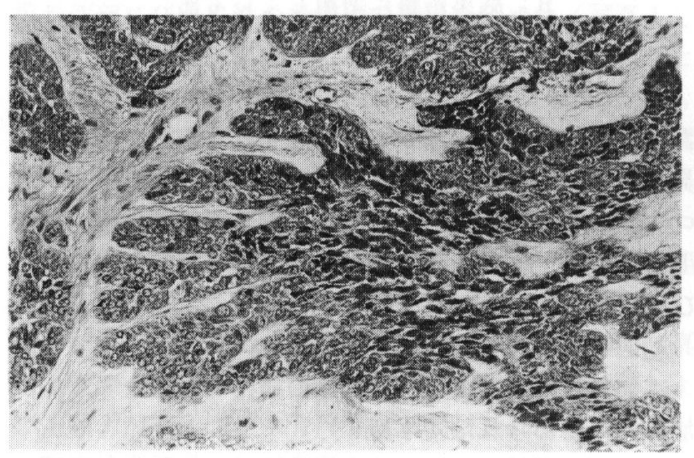

写真 11 クロマチンに富み, 細胞や核の異型が顕 著な部 ( $\mathrm{H}-\mathrm{E}$ 染色, 強扰大).

れた（写真 11）。また異型性の強い腫瘍細胞が 浸潤性に 増殖している部もあった（写真 12）。新生骨の形成は腫 瘍中央部から上顎骨前壁さらに圧排された上靧洞直下ま で，種々の程度で認められた。新生骨は一般に骨膜に向 かって細長く形成され，扮の扮のが瘾合し網目状とな り, これらの間にはしばしば島状や索状の腫瘍胞巣が増

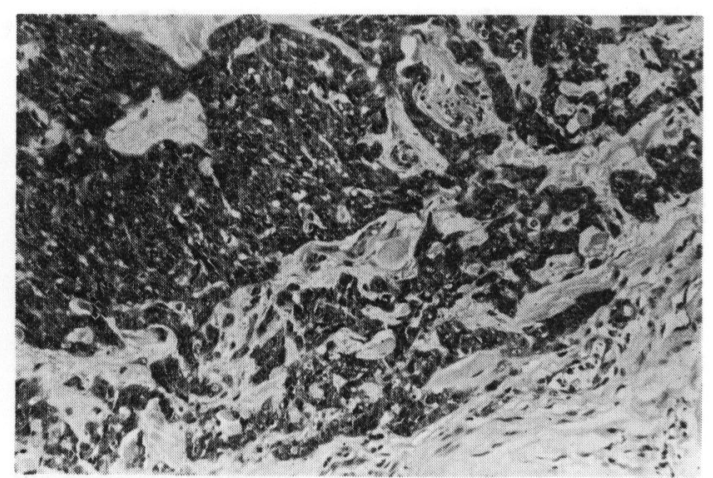

写真 12 異型細胞が浸潤性に増殖している(H-E 染色, 強拡大).

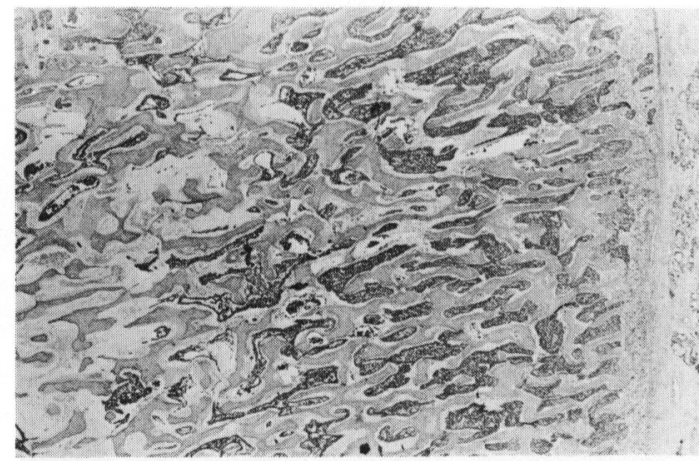

写真 13 新生骨の間に胞巣がみられる(H-E 染色, 弱桩大).

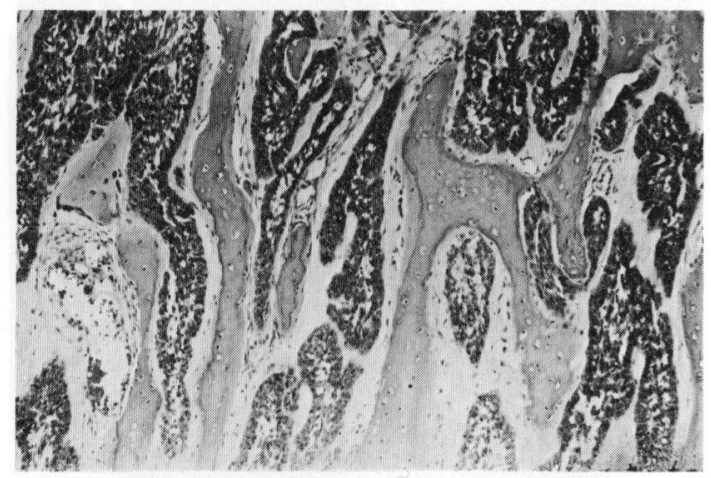

写真 14 新生骨に接して骨芽細胞が認められる (H-E 染色, 強拡大)

殖していた（写真 13）。また新生骨の周囲には 1 層の骨 芽細胞が並び（写真 14），一方腫瘍に接して 破骨細胞が 認められる部もあった。

病理組織診断 : 基底細胞型の悪性エナメル上皮腫,

再手術時の切除標本の病理組織所見 : 異型性を示す基 底細胞様細胞が大小不正形の胞巣を形成し骨内に充満し 


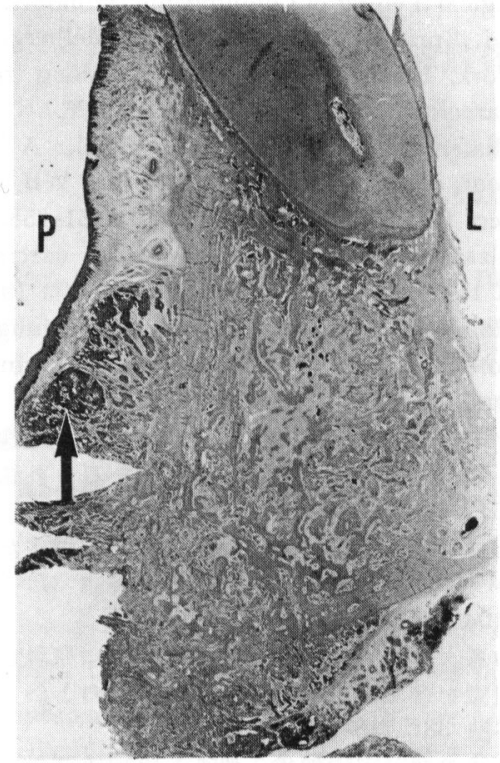

写真 15 再発切除標本の全割組織写真 骨内には腫瘍胞巣が充満し，口蓋粘膜下にまで増殖 している(1).

胞巣間には新生骨がみられる。

$\mathrm{L}$ ：唇側, P：口蓋側 ( $\mathrm{H}-\mathrm{E}$ 染色, 弱桩大).

ていたが，胞巣に接して活発な新生骨の形成や吸収が認 められた（写真 15）。また腫瘍は骨皮質を破壊し，上皮 下や歯根膜に浸潤していた（写真 16）.

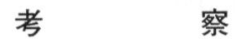

\section{1. 歯原性悪性腫瘍の分類, 特に悪性エナメル上皮腫 について}

1992年, WHO による歯原性腫瘍の分類が 21 年ぶりに 改訂された ${ }^{11}$. そのうちの上皮性の歯原性悪性腫瘍の分 類を以下に示す.

Odontogenic carcinomas

1. Malignant ameloblastoma.

2. Primary intraosseous carcinoma.

3. Malignant variants of other odontogenic epithelial tumours.

4. Malignant changes in odontogenic cysts.

前回の分類では malignant ameloblastoma は原発巣 および転移巣がエナメル上皮腫の組織像を呈するものと 定義され，転移の有無が診断基準となって㧍り，細胞の 異型性についての記述はなかった。すなわち旧分類で は, 細胞学的に悪性像を認めるェナメル上皮腫について は言及されていなかった。一方，1974年 Shafer ${ }^{2)}$ は組織 学的に悪性所見を認めるェナメル上皮腫を ameloblastic

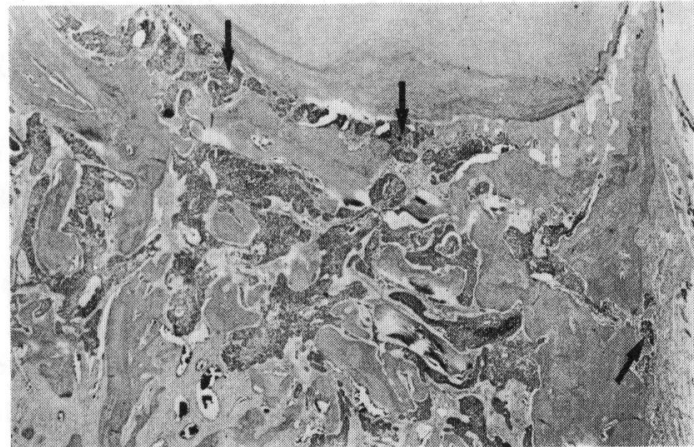

写真 16 根尖部の拡大写真, 歯根膜 $(\downarrow)$ や唇側骨 皮質の外侧（1）に腫瘍が浸潤している (H-E 染色, 強拡大).

(arcinoma と呼び， Elzay ${ }^{3) や S l o o t w e g ら ~}{ }^{4)}$ がそれを踏ま えて, 歯原性悪性腫瘍の分類を発表した。 今回の WHO の malignant ameloblastoma の定義では, 転移の有無 に関わらずェナメル上皮腫の組織学的構造を呈するが, 細胞学的な悪性所見を原発巣や転移巣に認めるものとな った。このためこれまで悪性エナィル上皮腫とされてき た転移性エナメル上皮腫, すなわち原発巣も転移巣も組 織学的に悪性所見が認められない場合は新分類では該当 するところがなくなった。削除された理由は不明である が，転移症例では病理組織検査を厳重に行うと, どこか に異型像を示す部が認められるといらことであろらか.

本例は濾胞型の増殖様式を示しているが, 腫瘍細胞の 多くは基底細胞様であったため, 基本的には基底細胞型 エナメル上皮腫と考光られた。しかし転移は認められ ないが, 細胞学的悪性がみられたことから最終的には malignant ameloblastoma と診断した。なお基底細胞癌 や腺癌とは, 典型的なエナメル骨道様構造や角化巣が散在 性に認められたこと, および腺管状構造がみられず, PAS 染色陰性であったことなどから鑑別した。

\section{2. 骨形成像について}

エナメル上皮腫の内部にとさに骨形成像を認めること がある，宇治ら ${ }^{5)}$ はこの形成機序に関して，11腫瘍の浸 潤增殖に伴い既存の骨梁が吸収と新生により形態を変え て残存したもの，(2)混合腫瘍と考劣る場合であるが，間 質である結合組織が歯原性線維腫で, 硬組織の形成を行 う, (3)間質の結合組織線維の化生による石灰化の 3 通り の説をあげているが，(1)の説が最も無理なくあてはまる と述べ, 石神ら ${ }^{6)}$ 扎よび中島ら ${ }^{7)}$ も同様に考光ている. 一方，藤元ら ${ }^{8)}$ は間質の線維成分による線維性化骨が主 体であるとし，竹本ら ${ }^{9)}$ は長期間の腫瘍の刺激によって 結合組織より骨形成能が惹起されたと考え, また Okada $5^{10)}$ も腫瘍増殖のバリヤーとして間質が骨を形成したと いらより，腫瘍細胞が間質の骨形成能を惹起したと考え た方がよいと述べている。 Takeda ら ${ }^{11)}$ は腫瘍細胞には 
骨の誘導能はなく, 形成された骨は反応性のものである としている. 自験例では過去の報告例と骨の形成様式が あきらかに異なっている。すなわちX線写真所見として 報告例では蜂巣状や斑状を呈するものが多かったが, 自 験例では右側上顎部が一様にスリガラス様となってい た. 本例に持ける摘出物の軟X線写真で, 上顎骨前壁に 認められた放射状の骨形成像は骨膜による著明な骨形成 を，また上顎洞が上方に押し上げられるように右側上顎 部が新生骨で置換された所見は, 上顎洞側の骨内膜性骨 新生と考えられた。一方, 組織学的には本例で観察され た骨は，宇治らが述べたような単なる骨改造による骨形 成とは考えられない，本例では新生骨間および骨膜直下 に多数の腫瘍胞巣を認め, あたかも腫瘍に骨形成が誘導 されたような所見であった。すなわち本腫瘍に特別な骨 誘導能があったか否かは不明であるが, 腫瘍の刺激によ り間葉組織に骨形成能が惹起され，それに骨膜や骨内膜 による骨形成が加わったものと思われる．放射状の骨形 成像は骨肉腫で観察されるが，本例も組織学的に悪性所 見を呈しており，腫瘍は速やかに骨膜下に浸潤増殖し骨 肉腫と同様の機序により骨膜性の反応性骨新生を生じた ものと推察される.

\section{結語}

著明な骨新生を伴った，きわめてまれな上顎の悪性エ ナメル上皮腫を経験したので組織学的検討を行い報告し た.

\section{引用文 献}

1) Kramer, I.R., Pindborg, J.J., et al.: Histo- logical Typing of Odontogenic Tumours. 2nd Ed, Springer-Verlag, Berlin, Heidelberg, New York, London, Paris, Tokyo, Hong Kong, Barcelona, Budapest, 1992, p 24-26.

2) Shafer, W.G., Hine, M.K., et al.: A Textbook of Oral Pathology, 3rd Ed, WB Saunders Co, Philadelphia, 1974, p 251-258.

3) Elzay, R.P.: Primary intraosseous carcinoma of the jaws. Oral Surg 54: 299-303 1982.

4) Slootweg, P.J. and Müller, H.: Malignant ameloblastoma or ameloblastic carcinoma. Oral Surg 57: 168-176 1984.

5）宇治保義，児玉国昭，他：興味ある組織像を呈 したエナメル上皮腫の 1 例. 日口外誌 29: 1512-1519 1983.

6）石神哲郎，杉原一正，他：骨組織を含んだ上顎 エナメル上皮腫の 1 例. 日口外誌 37：210321041991.

7) 中島 健, 野代忠宏, 他：高秢者に発現した骨 組織を含んだ上顎エナメル上皮腫の 1 例. 日口 外誌 38：146-147 1992.

8）藤元栄輔，窒木俊美，他：X線学的ならびに病 理組織学的に興味ある所見を示したエナメル上 皮腫の 1 例. 日口外誌 33: 810-817 1987 .

9) 竹本 隆, 山本敏康, 他 : 内部に骨組織を含九 だ上顎エナメル上皮腫の 1 例。 日口外誌 37 : 234-239 1991.

10) Okada, Y., Sugimura, M., et al.: Ameloblastoma accompanied by prominent bone formation. J Oral Maxillofac Surg 44: 5555571986.

11) Taheda, Y., Kuroda, M., et al.: Ameloblastoma with prominent stromal ossification. Acta Pathol Jpn 40: 780-784 1990. 